\title{
Acute double-valved endocarditis mimicking as COVID-19 pneumonia: a case report
}

\section{(D) Petar Martinčić ${ }^{*}$, iDDavor Barić², (D) Krešimir Šutalo'}

${ }^{1}$ General Hospital „Dr. Tomislav Bardek", Koprivnica, Croatia

${ }^{2}$ University Hospital Dubrava, Zagreb, Croatia

\author{
KEYWORDS: endocarditis, COVID-19, ventricular outflow obstruction, systolic murmurs. \\ CITATION: Cardiol Croat. 2021;16(5-6):194. | https://doi.org/10.15836/ccar2021.194
}

*ADDRESS FOR CORRESPONDENCE: Petar Martinčić, Opća bolnica „Dr. Tomislav Bardek“, Ulica Željka Selingera bb, HR-48000 Koprivnica, Croatia. / Phone: +385-98-922-425 / E-mail: petar.martincic@gmail.com

ORCID: Petar Martinčić, https://orcid.org/0000-0001-8141-1749 • Davor Barić, https://orcid.org/0000-0001-5955-0275 Krešimir Šutalo, https://orcid.org/0000-0003-0719-0065

|I||||||||||||||||||||||||||||||||||||||||||||||||||||||||||||||||||||||||||||||||||||||||||||||||||||||||||||||||||||||||

Aim: To report a case of a patient with undiagnosed endocarditis that presented as COVID-19 pneumonia.

Case report: 62-year-old woman with a history of arterial hypertension, presented to the Emergency Department of General Hospital Koprivnica with fever and cough lasting for 7 days and general fatigue lasting for 3 weeks. Her vital signs were in physiologic range, while auscultatory she had a systolic murmur over the whole precordium with diffuse pulmonary crackles. Chest radiograph showed bilateral interstitial pneumonia whilst laboratory results displayed elevated inflammatory markers, cardiac troponin and D-dimers combined with mild partial respiratory insufficiency. She was admitted to an isolated COVID-19 ward where empiric antibiotic therapy with ceftriaxone began in parallel with dexamethasone, dalteparin and oxygen therapy via nasal cannula. During the night of admission, she became hemodynamically unstable and fluid resuscitation in conjunction with inotropes was initiated. Emergency pulmonary CT angiography ruled out pulmonary embolism and showed bilateral ground-glass changes with pleural effusion as well as signs of venous congestion. Subsequently, COVID-19 was confirmed with the RT-PCR test. After a 10-day isolation period, she was transferred to the Cardiology Department where transthoracic echocardiography was performed. Massive vegetation on the anterior mitral leaflet that caused obstruction of the left ventricular outflow tract and moderate mitral regurgitation with filiform vegetation on the aortic valve were shown. Initial antibiotic therapy was swapped to amikacin and gentamicin. Further hospital stay was complicated with paroxysmal atrial fibrillation, worsening of heart failure and psychological disturbance. Indication for emergency valve replacement and transfer to the University Hospital Dubrava was indicated. Intraoperatively, massive vegetation on A1/A2 section of mitral leaflet and a smaller vegetation on ventricular side of left and noncoronary cusps of the aortic valve were visible. Both valves were replaced with mechanical valves with satisfying results and the patient was returned to the parent hospital. Coagulase-negative $S$. aureus susceptible to vancomycin was later verified on the mitral leaflet specimen.

Conclusion: Despite our focus on SARS-CoV-2 pandemic, it is important not to neglect other diagnosis and usefulness of echocardiography as a powerful diagnostic tool in everyday clinical practice..$^{1-3}$

\section{RECEIVED:}

March 28, 2021

ACCEPTED:

April 2, 2021

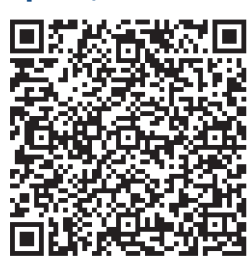

$\square$ Cardiologia Croatica 2021;16(5-6):194.
CroEcho2021

$11^{\text {th }}$ Croatian Biennal Echocardiography Congress with International Participation / 11. hrvatski dvogodišnji ehokardiografski kongres s međunarodnim sudjelovanjem Virtual Congress, May 6-8, 2021
LITERATURE IIIIIIIIIIIIIIIIIIIIIIIIIIIIIIIIIIIIIIIIIIIIIIIIIIIIIIIIIIIIIIIIIIIIIIIIIIIIIIIIIIIIIIIIIIIIIIIIIIIIIIIIIIIIIIIII

1. Habib G, Badano L, Tribouilloy C, Vilacosta I, Zamorano JL, Galderisi M, et al; European Association of Echocardiography. Recommendations for the practice of echocardiography in infective endocarditis. Eur J Echocardiogr. 2010 Mar;11(2):202-19. https://doi.org/10.1093/ejechocard/jeq004

2. AATS Surgical Treatment of Infective Endocarditis Consensus Guidelines Writing Committee Chairs, Pettersson GB, Coselli JS; Writing Committee, Pettersson GB, Coselli JS, Hussain ST, Griffin B, Blackstone EH, Gordon SM, et al. 2016 The American Association for Thoracic Surgery (AATS) consensus guidelines: Surgical treatment of infective endocarditis: Executive summary. J Thorac Cardiovasc Surg. 2017 Jun;153(6):1241-1258. e29. https://doi.org/10.1016/j.jtcvs.2016.09.093

3. Habib G, Hoen B, Tornos P, Thuny F, Prendergast B, Vilacosta I, et al; ESC Committee for Practice Guidelines. Guidelines on the prevention, diagnosis, and treatment of infective endocarditis (new version 2009): the Task Force on the Prevention, Diagnosis, and Treatment of Infective Endocarditis of the European Society of Cardiology (ESC). Endorsed by the European Society of Clinical Microbiology and Infectious Diseases (ESCMID) and the International Society of Chemotherapy (ISC) for Infection and Cancer. Eur Heart J. 2009 0ct;30(19):2369-413. https://doi.org/10.1093/eurheartj/ehp285 